\title{
A PROBABLE \\ LITTLE GULL RECORD \\ FOR SOUTHERN MANITOBA
}

\author{
by MARTIN K. McNICHOLL*
}

In late September, 1970, I observed an oddly plumaged gull in a flock of Bonaparte's Gulls along the southern shore of Lake Dauphin in Manitoba. Although I was unable to identify the gull at the time, a comparison of my notes with descriptions in the literature convinces me that I observed an immature Little Gull in a little known plumage. As the record was not verified by other observers and not substantiated with photographs or a specimen, it must remain hypothetical. However, in view of the rarity of the bird and high probability it was a Little Gull, I wish to place the observation on record. Hopefully this note will alert others of the features of this gull.

The gull in question was somewhat smaller than its companion Bonaparte's Gulls, but its tern-like flight and feeding behaviour was similar to theirs. Both the mystery bird and the Bonaparte's Gulls also showed a distinct terminal tail band, light feet and black spot behind the eye, at the level of the ear. However the smaller gull differed in having a squared-off not rounded tail. In addition the brownish bar crossing the Bonaparte's wing diagonally from the body at a point anterior to the trailing edge of the wing to the carpal joint, was replaced on this bird by a similarly placed black bar. These

*Dept. of Zoology,

University of Ailberta,

Edmonton, Alberta.

T6G 2E1. behavioural, size and plumage features all agree with those given for the Little Gull in standard field guides and regional bird books, such as those by Godfrey, ${ }^{3} \mathrm{Hollam}^{4}$ and Peterson et al. ${ }^{8}$ However, the bird also had a rich brownish streak across the nape in the position of a black streak often said to help identify the immature Blacklegged Kittiwake and distinguish it from the Little Gull. ${ }^{*}{ }^{x}$ Thus, the bird on Lake Dauphin seemed to fit the descriptions of neither the Little Gull nor the Black-legged Kittiwake, differing from the latter in size, light feet and light nape bar. A paper by Ennis² seems to clarify this puzzle. He described several cases of Little Gulls in Great Britain in typical immature plumage except for a "sepia bar across the nape," just like the bird I observed. Thus the gull on Lake Dauphin was very likely an immature Little Gull.

The Little Gull is an old-world species of which there were extremely few records for North America early in this century. ${ }^{7}$ Records for eastern North America, especially the Maritimes and New England became increasingly frequent however until the species became regular there, ${ }^{1}: 3$ culminating in an Ontario breeding record in 1962.' "Records for the prairie provinces, however, are scarce. An old, often quoted, record for Saskatchewan is uncertain at best," but one was collected on Lake Athabasca in 1962, ${ }^{6}$ and another observed and photographed in Regina in 1973.13 The 
only Manitoba record of which I am aware is of one seen at Churchill in July of 1970." No records appear to exist for either Alberta or North Dakota. ${ }^{10}$ 12

'BAILLIE, J. L. 1963. Three bird immnigrants from the Old World. Trans. of the Royal Canadian Inst. 34(part 2): 95-105.

"ENNIS, T. 1969. Field-characters of immature Little Gulls and Kittiwakes. British Birds 62: 234-237.

"GODFREY, W. E. 1966. The birds of Canada. Natl. Mus. of Canada Bull. 203, Ottawa. 428 pp.

'HOUSTON, C. S. 1958. An evaluation of the distribution records for Saskatchewan birds in the revised edition of the A.O.U. check-list. Blue Jay 16: $44-47$.
"NERO, R. W. 1962. Birds of the Lake Athabasc region, Saskatchewan. Spec. Publ. No. 5, Sask Nat. Hist. Soc., Regina. 143 pp.

${ }^{7}$ NORTON, A. H. 1910. The Litrle Gull Laru minutus Pall. in Maine, with rernarks on it distribution and occurrence in America. Auk. 27 447-450.

'PETERSON, R. T., G. MOUNTFORD and P. A. D. HOLLAM. 1966. A field guide to the hirds of Britain and Europe (revised edition). Collins, London. xxxv + 344 pp.

"PITTAWAY, R., and R. W. NERO. 1971 Recert bird notes of interest for Churchill, Manitoba. Blue Jay 29: 60-63.

"'SALT, W. R., and A. L. WILK. 1966. The birds of Alberta (second ed.). Dept. of Industry and Devel., Alberta Government. 511 pp.

"SCOTT, G. A. 1963. First nesting of the Little' Gull (Larus minutus) in Ontario and in the New World. Auk 80: 548-549.

"STEWART, R. E. 1971. Check list of hirds in North Dakota. Prairie Nat. 3: 3-12.

1:SWITZER, F. 1974. Little Gull visits Regina. Blue Jay 32: $46-48$.

\section{MORE GREAT CRESTED FLYCATCHERS AND SHORT-BILLED MARSH WRENS IN ALBERTA}

by WAYNE C. WEBER*

On the morning of June 15, 1972, I observed a Great Crested Flycatcher near the Administration Office in Elk Island National Park, Alberta, about 25 miles east of Edmonton. After initially identifying the bird, I left and returned shortly with Marg Reine, then Acting Park Naturalist, and Ken Richards, Seasonal Park Naturalist. The three of us watched the bird for

*302, 170 East Fourth Street,

North Vancouver, B.C..

V7L IH6. about 10 minutes. During this time, I recorded in my field notes that the bird was about the size of an Eastern Kingbird, with an ashy-gray throat and upper breast and a pale yellow lower breast and abdomen. The head and upperparts were a medium brown colour and the tail was rufous, with a suggestion of rufous in the wings as well. The calls were noted as an upslurred "wheep!" and a rolling "breer! breer!". The bird was not seen again in 1972, despite almost daily visits to this locality. 